\title{
The role of tyrosine kinases in capacitative calcium influx-mediated aldosterone production in bovine adrenal zona glomerulosa cells
}

\author{
H B Aptel, M M Burnay, M F Rossier ${ }^{1}$ and A M Capponi \\ Division of Endocrinology and Diabetology, Department of Internal Medicine, University Hospital, CH-1211 Geneva 14, Switzerland \\ ${ }^{1}$ Laboratory of Clinical Chemistry, Department of Pathology, University Hospital, $\mathrm{CH}-1211$ Geneva 14, Switzerland \\ (Requests for offprints should be addressed to A Capponi, Division of Endocrinology and Diabetology, University Hospital, 24, Micheli-du-Crest, \\ CH-1211 Geneva 14, Switzerland; Email: capponi@cmu.unige.ch)
}

\begin{abstract}
In adrenal glomerulosa cells, the stimulation of aldosterone biosynthesis by angiotensin II (Ang II) involves the activation of a capacitative $\mathrm{Ca}^{2+}$ influx through calcium release-activated calcium (CRAC) channels. In various mammalian cell systems, it has been shown that CRAC channel activation and $\mathrm{Ca}^{2+}$ entry require tyrosine kinase activity. We have therefore examined in this work whether similar mechanisms contribute to Ang II-induced mineralocorticoid biosynthesis. In fluo-3-loaded isolated bovine glomerulosa cells, two inhibitors of tyrosine kinases, genistein and methyl-2,5-dihydroxycinnamate $(\mathrm{MDHC})(100 \mu \mathrm{M})$ prevented capacitative $\mathrm{Ca}^{2+}$ entry elicited by Ang II (by 54 and 62\% respectively), while the inhibitor of epidermal growth factor (EGF) receptor tyrosine kinase, lavendustin A, was without effect. Similar results were observed on $\mathrm{Ca}^{2+}$ influx triggered by thapsigargin, an inhibitor of microsomal $\mathrm{Ca}^{2+}$ pumps. The
\end{abstract}

inhibitors blocked Ang II-stimulated pregnenolone and aldosterone production in the same rank order. In addition to its specific effect on capacitative $\mathrm{Ca}^{2+}$ influx, genistein also affected the late steps of the steroidogenic pathway, as shown by experiments in which the rate-limiting step (intramitochondrial cholesterol transfer) was bypassed with 25-OH-cholesterol (25-OH-Chol), cytosolic calcium was clamped at stimulated levels or precursors of the late enzymatic steps were supplied. In contrast, genistin, a structural analogue of genistein devoid of tyrosine kinase inhibitory activity, was almost without effect on pregnenolone or 11-deoxycorticosterone (DOC) conversion to aldosterone. These results suggest that, in bovine adrenal glomerulosa cells, Ang II promotes capacitative $\mathrm{Ca}^{2+}$ influx and aldosterone biosynthesis through tyrosine kinase activation.

Journal of Endocrinology (1999) 163, 131-138

\section{Introduction}

The involvement of tyrosine kinases in the signal transduction processes triggered by various growth factors such as epidermal growth factor (EGF) or platelet-derived growth factor is now clearly established (Marshall 1995). In addition, it appears that protein tyrosine phosphorylation is also involved in a variety of responses not directly related to cell growth. For example, tyrosine kinase activity participates in the control of smooth muscle contractility (Yang et al. 1993). The mechanisms of cytosolic $\mathrm{Ca}^{2+}$ homeostasis are also known targets for tyrosine kinases: for instance, phospholipase $\mathrm{C} \gamma_{1}$ interacts directly with tyrosine kinase receptors through its $\mathrm{SH} 2$ domains, an interaction which leads to phospholipase phosphorylation and activation, and therefore to the formation of inositol 1,4,5-trisphosphate $\left(\operatorname{Ins}(1,4,5) \mathrm{P}_{3}\right)$ and to the release of $\mathrm{Ca}^{2+}$ from internal stores (Marrero et al. 1994, Rhee \& Bae 1997). Furthermore, it has been shown that tyrosine kinase inhibitors, such as genistein and methyl-2,5dihydroxycinnamate (MDHC), inhibit $\mathrm{ADP}-$ and thapsigargin-stimulated $\mathrm{Ca}^{2+}$ entry in human platelets (Sargeant et al. 1993) and that bradykinin- and thapsigargin-induced $\mathrm{Ca}^{2+}$ influx into human foreskin fibroblasts can be blocked by tyrosine kinase inhibitors (Lee et al. 1993).

In adrenal zona glomerulosa cells, the octapeptide hormone, angiotensin II (Ang II) is, with extracellular potassium, the main regulator of aldosterone biosynthesis. Ang II elicits biphasic changes in cytosolic free calcium concentration, $\left[\mathrm{Ca}^{2+}\right]_{\mathrm{c}}$ : an initial peak of $\left[\mathrm{Ca}^{2+}\right]_{\mathrm{c}}$ resulting from $\operatorname{Ins}(1,4,5) \mathrm{P}_{3}$-induced emptying of intracellular stores is followed by a sustained calcium influx mainly due to capacitative $\mathrm{Ca}^{2+}$ entry through calcium release-activated calcium (CRAC) channels (Putney \& Bird 1993, Burnay et al. 1994). This sustained $\mathrm{Ca}^{2+}$ influx is known to be essential for a full steroidogenic response (Burnay et al. 1994). It was therefore of interest to study whether, like in other cell types, tyrosine kinases can regulate CRAC channel activity and steroidogenic response in adrenal glomerulosa cells. Using freshly isolated bovine glomerulosa cells, we have examined the effect of two tyrosine 
kinase inhibitors on the $\left[\mathrm{Ca}^{2+}\right]_{\mathrm{c}}$ signals and aldosterone production elicited by Ang II and thapsigargin, an inhibitor of microsomal $\mathrm{Ca}^{2+}$ pumps and an activator of the capacitative pathway.

\section{Materials and Methods}

\section{Materials}

Nicardipine, 25-hydroxycholesterol (25-OH-Chol), Hepes, insulin, transferrin, sodium selenite were purchased from Sigma (St Louis, MO, USA). Thapsigargin, genistein, genistin, MDHC and lavendustin A were obtained from Anawa (Zurich, Switzerland). Ionomycin was purchased from Calbiochem (Lucerne, Switzerland) and $\left[\mathrm{Ile}^{5}\right]$ AngII from Bachem AG (Bubendorf, Switzerland). Dispase (grade II) was obtained from Boehringer Mannheim (Indianapolis, IN, USA) and Percoll from Pharmacia (Piscataway, NJ, USA). Horse serum, fetal calf serum, and Dulbecco's modified Eagle's medium (DMEM) were obtained from Gibco (Grand Island, NY, USA). Fluo-3 acetoxymethylester (fluo-3/ AM) and pluronic acid were purchased from Molecular Probes (Eugene, OR, USA) and metyrapone from Aldrich (Milwaukee, WI, USA). $\left[{ }^{3} \mathrm{H}\right]$ pregnenolone was obtained from DuPont NEN (Boston, MA, USA), rabbit polyclonal antibody directed against pregnenolone from Biogenesis (Poole, Dorset, UK), and WIN 19'758 (cyanoketone) was kindly donated by Sterling-Winthrop (Rensselaer, NY, USA).

\section{Isolation and culture of bovine glomerulosa cells}

Bovine adrenal glomerulosa cells were prepared by enzymatic dispersion with dispase and purified on a Percoll gradient, as described in detail elsewhere (Rossier et al. 1993). Cells were then either used the same day, for measurement of $\left[\mathrm{Ca}^{2+}\right]_{\mathrm{c}}$ and aldosterone or pregnenolone production, or cultured on 24-well tissue culture plates. In the latter case, cells were transferred into antibioticcontaining DMEM supplemented with $2 \mu \mathrm{g} / \mathrm{ml}$ insulin, $2 \mu \mathrm{g} / \mathrm{ml}$ transferrin, $2 \mathrm{ng} / \mathrm{ml}$ sodium selenite, $5 \mu \mathrm{M}$ metyrapone, $2 \mathrm{mM}$ glutamine, 6 units $/ \mathrm{ml}$ nystatin, $2 \%$ (vol/vol) fetal calf serum and 10\% (vol/vol) horse serum, plated in 24-well tissue culture dishes (500 000 cells/well) and incubated overnight at $37{ }^{\circ} \mathrm{C}$ in $5 \% \mathrm{CO}_{2}$. The next day, the medium was removed and replaced with serumfree DMEM and the cells were used 3-4 days after plating as described elsewhere (Rossier et al. 1993).

\section{Measurement of $\left[\mathrm{Ca}^{2+}\right]_{c}$}

The determination of $\left[\mathrm{Ca}^{2+}\right]_{c}$ in cell populations was performed with the fluorescent probe fluo-3. For this purpose, cells purified on Percoll gradients were washed twice and resuspended in a modified Krebs-Ringer medium (containing $136 \mathrm{mM} \mathrm{NaCl}, 1.8 \mathrm{mM} \mathrm{KCl}$, $1.2 \mathrm{mM} \mathrm{KH} \mathrm{PO}_{4}, 1.2 \mathrm{mM} \mathrm{MgSO}$, $5 \mathrm{mM} \mathrm{NaHCO}$, $1.2 \mathrm{mM} \mathrm{CaCl}_{2}$ and $5.5 \mathrm{mM} \mathrm{D}$-glucose and buffered at $\mathrm{pH}$ $7 \cdot 4$ with $20 \mathrm{mM}$ Hepes) at a concentration of $10^{7}$ cells $/ \mathrm{ml}$, then incubated at $37{ }^{\circ} \mathrm{C}$ for $60 \mathrm{~min}$ before being washed and incubated again for $45 \mathrm{~min}$ in the presence of $6 \mu \mathrm{M}$ Fluo-3/AM and 12.5\% (w/v) pluronic acid. Excess dye was washed out, and the cells were kept at ambient temperature in the same medium. Aliquots $\left(3 \times 10^{6}\right.$ cells $)$ were sedimented just before use and resuspended in $2 \mathrm{ml}$ Krebs-Ringer medium in a thermostated cuvette at $37^{\circ} \mathrm{C}$. Fluo-3 fluorescence (excitation at $470 \mathrm{~nm}$ and emission at $540 \mathrm{~nm}$ ) was recorded with a Jasco CAF-110 fluorescence spectrometer (Hachioji City, Japan) and $\left[\mathrm{Ca}^{2+}\right]_{\mathrm{c}}$ was calibrated as previously described for fura-2 (Grynkiewicz et al. 1985), using a $\mathrm{K}_{\mathrm{d}}$ of $390 \mathrm{nM}$.

\section{Determination of steroid production}

After dispersion and washing, freshly prepared glomerulosa cells were resuspended in $50 \mathrm{ml}$ modified KrebsRinger medium, preincubated for $60 \mathrm{~min}$ at $37^{\circ} \mathrm{C}$ before being washed twice and distributed at a final concentration of $500000 \mathrm{cell} / \mathrm{ml}$ in test tubes containing various agonists. Cells were then incubated for $90 \mathrm{~min}$ at $37^{\circ} \mathrm{C}$. Experiments with clamped cytosolic calcium were performed as described elsewhere (Python et al. 1995). Briefly, cells were resuspended in $\mathrm{Ca}^{2+}$-free Krebs-Ringer buffer (containing $0.2 \mathrm{mM}$ EGTA) and incubated for $120 \mathrm{~min}$ at $37^{\circ} \mathrm{C}$ in the presence of $2 \mu \mathrm{M}$ ionomycin, of various concentrations of total extracellular calcium, $\left[\mathrm{Ca}^{2+}\right]_{\text {ext }}$, and of various tyrosine kinase inhibitors. At the end of the incubation period, cells were sedimented by centrifugation, and the aldosterone content in the medium was measured by direct radioimmunoassay using a commercially available kit (Diagnostic Systems Laboratories, Webster, TX, USA).

When cells were used in primary culture, the serumfree medium was replaced with modified Krebs-Ringer medium at $37^{\circ} \mathrm{C}$ at least $1 \mathrm{~h}$ before starting the experiment. Cells were then incubated in the same medium containing various agonists for $90 \mathrm{~min}$. After $30 \mathrm{~min}$ incubation, media were replaced with fresh media of identical composition, and aldosterone was determined in the supernatant after $60 \mathrm{~min}$ of further incubation. Cellular protein content was measured in each well using the Coomassie blue method of Bradford (1976).

For pregnenolone production, Win 19'758 $(5 \mu \mathrm{M})$ was included in the incubation medium to prevent conversion of pregnenolone into progesterone. The pregnenolone content in the medium was determined by direct radioimmunoassay using $\left[{ }^{3} \mathrm{H}\right]$ pregnenolone (Python et al. 1995). 
A $\quad$ B

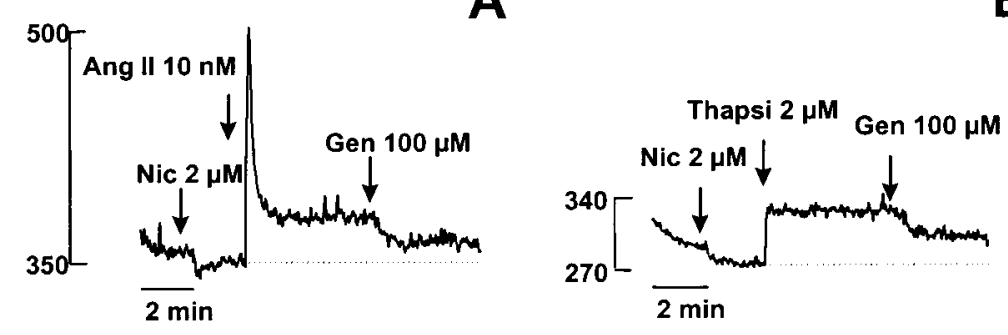

C D

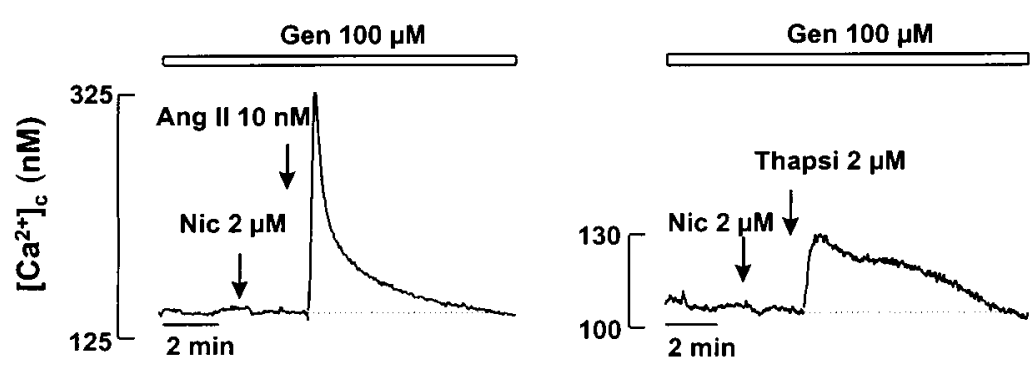

E $\quad F$
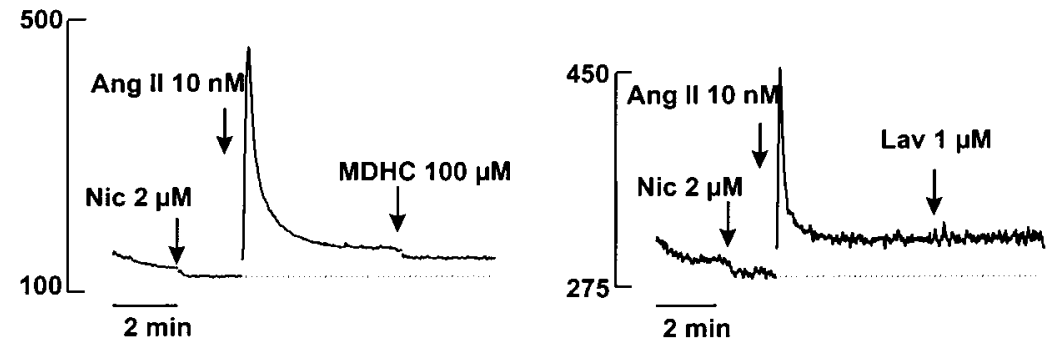

Figure 1 Effect of genistein (Gen), MDHC and lavendustin A (Lav) on the capacitative $\mathrm{Ca}^{2+}$ influx induced by Ang II or thapsigargin (Thapsi). Fluo-3-loaded bovine glomerulosa cells were challenged with Ang II $(A, C)$ or Thapsi $(B, D)$, in the presence of nicardipine (Nic), and Gen was added either 3 min after $(A, B)$ or before $(C, D)$ stimulation. E, F: Effect of $\mathrm{MDHC}$ and Lav respectively, on the Ang II-induced $\left[\mathrm{Ca}^{2}\right]_{\mathrm{C}}$ response. Each trace is representative of five independent experiments.

\section{Statistics}

Statistical significance of differences was assessed by the Student's $t$-test and is indicated with the two-tailed $P$ value.

\section{Results}

Effect of tyrosine kinase inhibitors on capacitative $\mathrm{Ca}^{2+}$ influx in bovine glomerulosa cells

We first examined the effect of genistein, a known inhibitor of tyrosine kinases, on Ang II- and thapsigargininduced capacitative $\mathrm{Ca}^{2+}$ influx. For this purpose, freshly prepared, fluo-3-loaded bovine glomerulosa cells were challenged with Ang II or thapsigargin and genistein $(100 \mu \mathrm{M})$ was added either $3 \mathrm{~min}$ after or $3 \mathrm{~min}$ before stimulation. Nicardipine $(2 \mu \mathrm{M})$, a dihydropyridine blocker of voltage-gated $\mathrm{Ca}^{2+}$ channels, was present in all experiments, in order to isolate the capacitative component of the $\mathrm{Ca}^{2+}$ influx response (Burnay et al. 1994). Ang II induced the expected biphasic $\left[\mathrm{Ca}^{2+}\right]_{c}$ response and genistein reduced the sustained phase by $54 \cdot 1 \pm 16 \cdot 2 \%$ $\left(n=5, P<0 \cdot 01\right.$ versus controls) when added during $\mathrm{Ca}^{2+}$ influx (Fig. 1A and Table 1). Similarly, genistein significantly decreased the plateau $\left[\mathrm{Ca}^{2+}\right]_{c}$ response elicited by thapsigargin by $62 \cdot 4 \pm 16 \cdot 1 \%(n=5, P<0 \cdot 01)$ (Fig. $1 \mathrm{~B}$ and Table 1). When genistein was added before stimulation, 
Table 1 Effect of genistein on Ang II- and thapsigargin-induced $\left[\mathrm{Ca}^{2+}\right]_{\mathrm{C}}$ changes in bovine adrenal glomerulosa cells. Fluo-3-loaded bovine glomerulosa cells were challenged with Ang II or thapsigargin in the presence of nicardipine and genistein was added 3 min after stimulation. The effect of genistein was calculated as the mean of the percent differences $(\Delta \%)$ between plateau $\left[\mathrm{Ca}^{2+}\right]_{\mathrm{C}}$ measured before and after genistein addition in each experiment $(n=5)$

\begin{tabular}{|c|c|c|c|c|}
\hline & $\begin{array}{l}\text { Angiotensin II } \\
10 \mathrm{nM}(n=5)\end{array}$ & $\begin{array}{l}\Delta \\
(\%)\end{array}$ & $\begin{array}{l}\text { Thapsigargin } \\
2 \mu \mathrm{M}(n=5)\end{array}$ & $\begin{array}{l}\Delta \\
(\%)\end{array}$ \\
\hline \multicolumn{5}{|l|}{$\begin{array}{l}{\left[\mathrm{Ca}^{2+}\right]_{\mathbf{c}}} \\
(\mathrm{nM})\end{array}$} \\
\hline Basal & $242 \pm 49$ & & $268 \pm 42$ & \\
\hline Basal+ nicardipine & $226 \pm 48$ & & $251 \pm 41$ & \\
\hline Peak & $431 \pm 75$ & & & \\
\hline Plateau & $253 \pm 40$ & & $295 \pm 43$ & \\
\hline Plateau+genistein & $232 \pm 39$ & $\begin{array}{l}-54 \pm 16 \\
P<0 \cdot 01\end{array}$ & $284 \pm 43$ & $\begin{array}{l}-62 \pm 16 \\
P<0 \cdot 01\end{array}$ \\
\hline
\end{tabular}

the plateau phase of the $\left[\mathrm{Ca}^{2+}\right]_{\mathrm{c}}$ response to Ang II was practically abolished (Fig. 1C) and the response to thapsigargin was no longer sustained (Fig. 1D). No significant effect of genistein was observed on the amplitude of the initial $\left[\mathrm{Ca}^{2+}\right]_{c}$ peak elicited by Ang II $\left(243 \pm 78 \mathrm{nM}\right.$ above basal $\left[\mathrm{Ca}^{2+}\right]_{c}$ in the absence of genistein and $166 \pm 11 \mathrm{nM}$ above basal with genistein pretreatment; $P=0 \cdot 42, n=5)$

MDHC $(100 \mu \mathrm{M})$, another tyrosine kinase inhibitor, also exerted a significant blockade of Ang II-induced capacitative $\mathrm{Ca}^{2+}$ influx $(40 \cdot 6 \pm 3 \%$ inhibition, $n=5$, $P<0.01$ versus controls) (Fig. 1E). In contrast, the inhibitor of EGF receptor tyrosine kinase, lavendustin A, at the reported optimal concentration, was without effect on the $\left[\mathrm{Ca}^{2+}\right]_{\mathrm{c}}$ response to Ang II (Fig. 1F).

Effect of tyrosine kinase inhibitors on Ang II-induced steroidogenesis in bovine glomerulosa cells

Because an activation of CRAC channels is known to be crucial for a full steroidogenic response to Ang II, the inhibition of capacitative $\mathrm{Ca}^{2+}$ influx should be matched by a reduction in steroid biosynthesis. Indeed, in freshly isolated bovine glomerulosa cells, both genistein and MDHC inhibited Ang II-induced formation of pregnenolone, the first step of the steroidogenic cascade, in a concentration-dependent manner, with an $\mathrm{IC}_{50}$ of approximately $80 \mu \mathrm{M}$ (Fig. 2A). Interestingly, while MDHC prevented Ang II-stimulated aldosterone production with similar efficacy, the $\mathrm{IC}_{50}$ of genistein was much lower $(11 \cdot 0 \pm 1 \cdot 4 \mu \mathrm{M}, n=3)$ (Fig. 2B).

As it can be seen in Fig. $3 \mathrm{~A}$ and $\mathrm{B}$, genistein and MDHC inhibited Ang II-stimulated pregnenolone and aldosterone production, measured in the presence of nicardipine, with the same order of potency observed for inhibition of the capacitative $\mathrm{Ca}^{2+}$ influx. In contrast, lavendustin, which was without effect on $\mathrm{Ca}^{2+}$ entry, did not affect steroid production.

Effect of tyrosine kinase inhibitors on 25-OH-cholesterol-induced steroidogenesis

The efficacy of genistein (Fig. 3B) suggested that this drug might inhibit aldosterone production by affecting not only the $\mathrm{Ca}^{2+}$ messenger system but also some steps of the steroidogenic cascade. To test this hypothesis, we measured pregnenolone and aldosterone production in bovine glomerulosa cells in response to $25-\mathrm{OH}-\mathrm{Chol}$, a hydrophilic derivative of cholesterol that bypasses the rate-limiting step of intramitochondrial transport. As shown in Fig. 4A and B, while none of the three tested tyrosine kinase inhibitors affected 25-OH-Chol-supported pregnenolone production, genistein $(100 \mu \mathrm{M})$ markedly reduce $25-\mathrm{OH}-\mathrm{Chol}-$ stimulated aldosterone biosynthesis (by $50 \cdot 5 \pm 6 \cdot 2 \%, n=5, P<0 \cdot 05)$. In contrast, MDHC $(100 \mu \mathrm{M})$ and lavendustin $\mathrm{A}(1 \mu \mathrm{M})$ did not alter steroid production in response to $25-\mathrm{OH}-\mathrm{Chol}$.

Effect of tyrosine kinase inhibitors on $\mathrm{Ca}^{2+}$-induced steroidogenesis

That genistein might impact on steps located downstream of the generation of the $\mathrm{Ca}^{2+}$ signal was further confirmed in experiments in which $\left[\mathrm{Ca}^{2+}\right]_{c}$ was clamped at various levels in bovine glomerulosa cells (Python et al. 1995). While $\mathrm{Ca}^{2+}$ elicited the expected increase in aldosterone output in a concentration-dependent manner, this response was markedly inhibited by genistein (Fig. 5).

\section{Effect of genistein on the conversion of progesterone and deoxycorticosterone to aldosterone}

To further localize the additional site of the inhibitory action of genistein, we examined its effect on the 

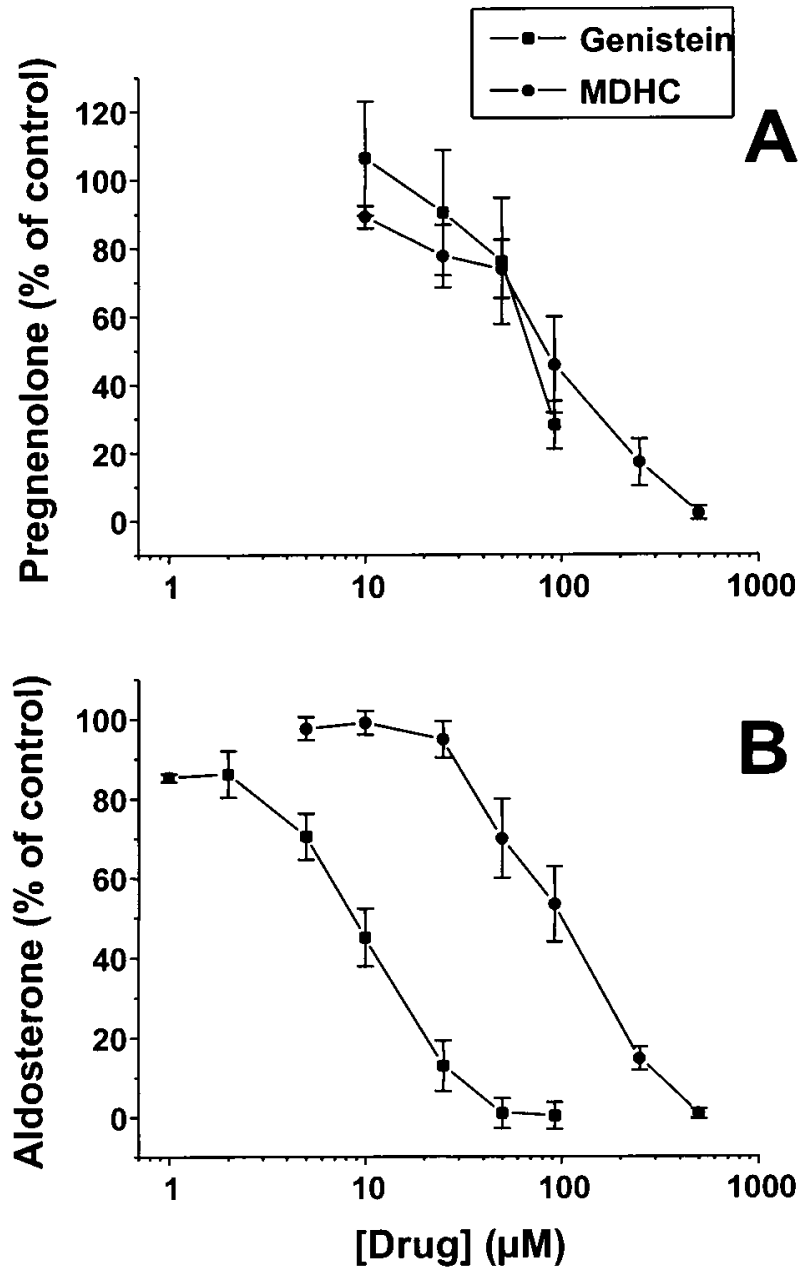

Figure 2 Concentration dependency of the effect of genistein and $\mathrm{MDHC}$ on Ang II-induced steroidogenesis. A) Freshly isolated bovine glomerulosa cells were incubated for $90 \mathrm{~min}$ at $37^{\circ} \mathrm{C}$ as described under Materials and Methods. Pregnenolone production was stimulated with $10 \mathrm{nM}$ Ang II, in the presence of increasing concentrations of genistein $(\boldsymbol{\square})$ and $\operatorname{MDHC}(\bullet)$. Pregnenolone levels in the medium were expressed as percentage of control stimulations in the presence of Ang II alone (33.5 $\pm 4.9 \mathrm{ng} / 10^{6}$ cell/90 min). Each point is the mean value \pm S.E.M. of between three and four independent experiments. B) Aldosterone production was stimulated as above and expressed as percentage of control stimulations $\left(11 \cdot 7 \pm 1 \cdot 8 \mathrm{ng} / 10^{6} \mathrm{cell} / 90 \mathrm{~min}\right)$. Each point is the mean value \pm S.E.M. of between four and five independent experiments.

conversion of progesterone $(10 \mu \mathrm{M})$ or 11-deoxycorticosterone (DOC, $10 \mu \mathrm{M})$ to aldosterone. Aldosterone formation from both precursors was inhibited in a concentrationdependent manner and with similar potency by genistein (Fig. 6). Interestingly, genistin $(100 \mu \mathrm{M})$, a structural analogue of genistein exhibiting little or no effect on tyrosine kinase activity, did not significantly alter either progesterone or DOC conversion to aldosterone (Table 2).
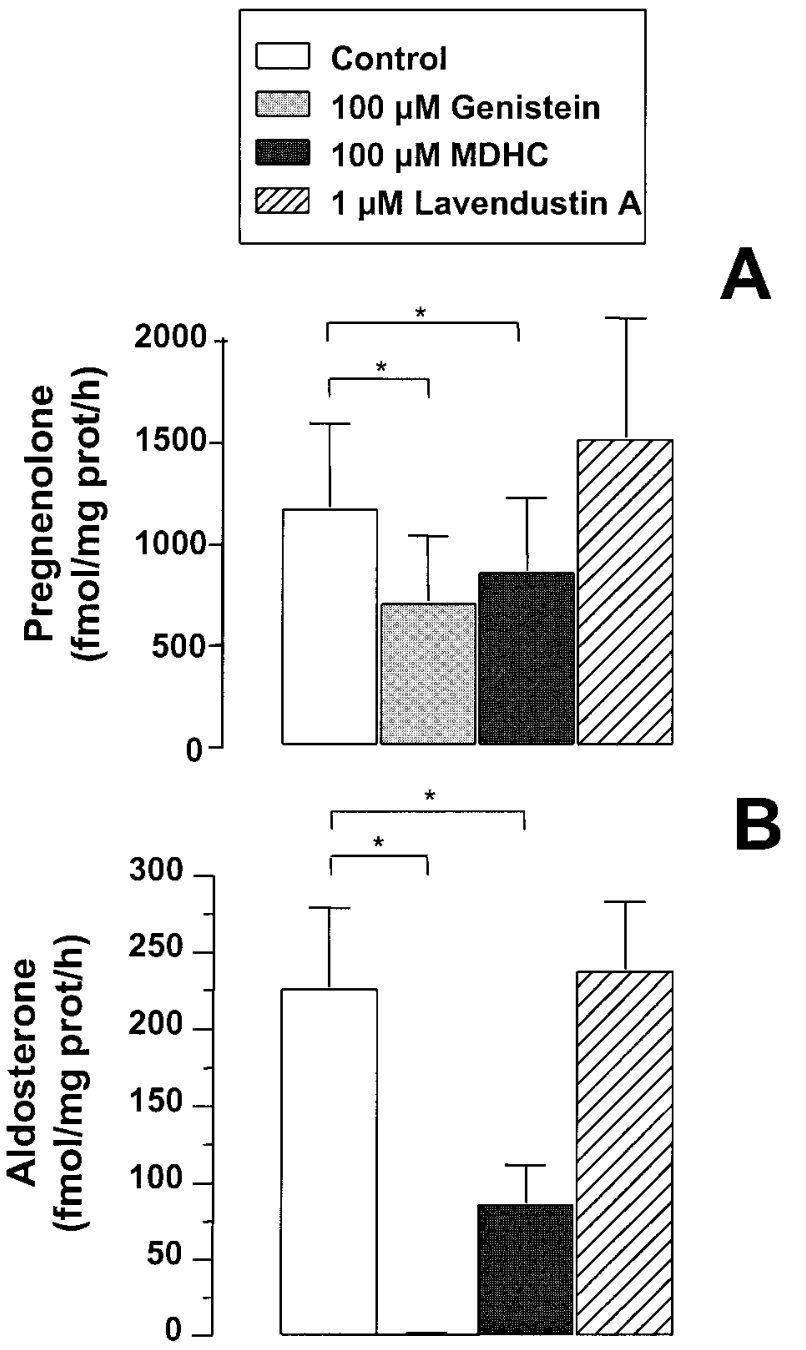

Figure 3 Effect of various tyrosine kinase inhibitors on steroidogenesis induced by capacitative calcium influx. Cultured bovine glomerulosa cells were prepared as described under Materials and Methods. Cells were stimulated for 60 min with Ang II $(10 \mathrm{nM})$, in the presence of nicardipine $(1 \mu \mathrm{M})$ and either $100 \mu \mathrm{M}$ genistein, $100 \mu \mathrm{M}$ MDHC or $1 \mu \mathrm{M}$ lavendustin $\mathrm{A}$ and pregnenolone $(\mathrm{A})$ or aldosterone $(\mathrm{B})$ production was determined as described. Each point is the mean value \pm S.E.M. of four independent experiments performed in triplicate. *Significantly different from controls in the presence of Ang II alone, with $P<0 \cdot 05$.

\section{Discussion}

The capacitative influx of calcium through CRAC channels plays a major role in the mechanism of activation of aldosterone biosynthesis by the octapeptide hormone, Ang II (Ely et al. 1991, Hajnoczky et al. 1991, Burnay et al. 1994, Rohacs et al. 1994). Although the cascade of events leading to the mobilization of $\mathrm{Ca}^{2+}$ from intracellular, $\operatorname{Ins}(1,4,5) \mathrm{P}_{3}$-sensitive stores in adrenal glomerulosa cells 

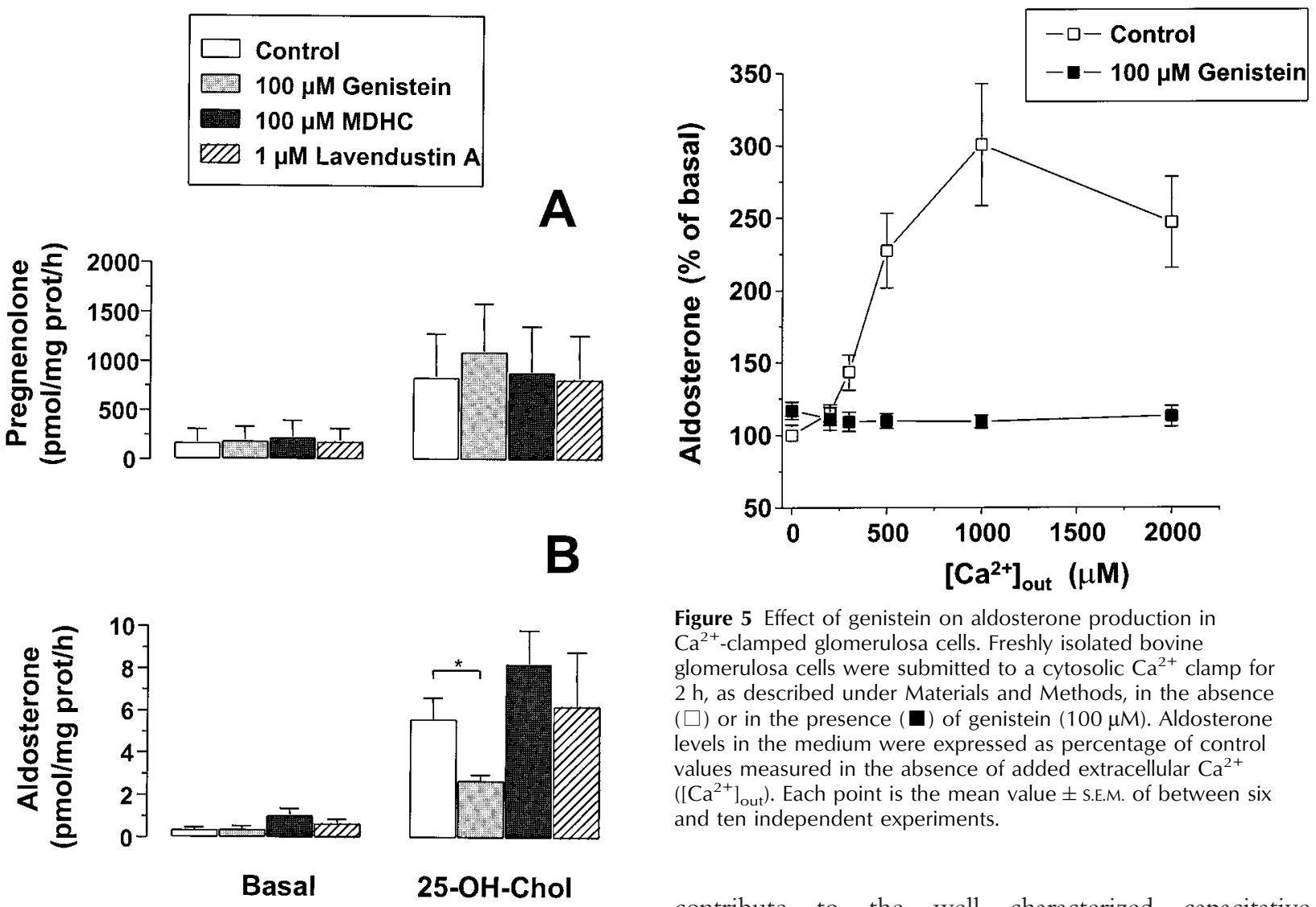

Figure 5 Effect of genistein on aldosterone production in $\mathrm{Ca}^{2+}$-clamped glomerulosa cells. Freshly isolated bovine glomerulosa cells were submitted to a cytosolic $\mathrm{Ca}^{2+}$ clamp for $2 \mathrm{~h}$, as described under Materials and Methods, in the absence $(\square)$ or in the presence $(\boldsymbol{\square})$ of genistein $(100 \mu \mathrm{M})$. Aldosterone levels in the medium were expressed as percentage of control values measured in the absence of added extracellular $\mathrm{Ca}^{2+}$ $\left(\left[\mathrm{Ca}^{2+}\right]_{\text {out }}\right)$. Each point is the mean value \pm S.E.M. of between six and ten independent experiments.

Figure 4 Effect of various tyrosine kinase inhibitors on 25-OH-Chol-supported steroidogenesis. Cultured bovine glomerulosa cells were prepared as described under Materials and Methods. Cells were stimulated for $60 \mathrm{~min}$ with $25-\mathrm{OH}-\mathrm{Chol}$ $(10 \mu \mathrm{M})$, in the presence of nicardipine $(1 \mu \mathrm{M})$ and either $100 \mu \mathrm{M}$ genistein, $100 \mu \mathrm{M} \mathrm{MDHC}$ or $1 \mu \mathrm{M}$ lavendustin $\mathrm{A}$ and pregnenolone $(\mathrm{A})$ or aldosterone $(\mathrm{B})$ production was determined as described. Each point is the mean value \pm S.E.M. of four independent experiments performed in triplicate. Basal:steroid production in the absence of $25-\mathrm{OH}-\mathrm{Chol}$. *Significantly different from controls in the presence of Ang II alone, with $P<0 \cdot 05$.

has been fairly well investigated (Barrett et al. 1989, Capponi \& Rossier 1996), the link between $\mathrm{Ca}^{2+}$ pool emptying and activation of CRAC channels remains to be elucidated. Several mechanisms such as calcium influx factor (CIF), G-proteins, protein-protein interaction, etc. have been invoked (Berridge 1995, Parekh \& Penner 1997). Among these potential modulators of capacitative $\mathrm{Ca}^{2+}$ influx, tyrosine kinases could play an important role. Indeed, various studies have shown that tyrosine kinase inhibitors prevent the $\left[\mathrm{Ca}^{2+}\right]_{c}$ response induced by thapsigargin or a $\mathrm{Ca}^{2+}$-mobilizing agonist (Lee et al. 1993, Sargeant et al. 1993, Pfeiffer et al. 1995, Flemming et al. 1996, Sharma \& Davies 1996, Takemura et al. 1997). The present work was therefore designed to assess whether, in bovine glomerulosa cells, tyrosine kinases

contribute to the well characterized capacitative $\mathrm{Ca}^{2+}$ influx and to the subsequent biological response, aldosterone biosynthesis.

The major finding of the present work is that two known inhibitors of tyrosine kinases, genistein (Constantinou \& Huberman 1995) and MDHC (Umezawa et al. 1990), blocked Ang II-induced capacitative $\mathrm{Ca}^{2+}$ influx in bovine adrenal glomerulosa cells. In these cells, $\mathrm{Ca}^{2+}$ influx through voltage-gated $\mathrm{T}$ - and L-type channels amounts to approximately $25 \%$ of the total influx under Ang II challenge (Burnay et al. 1994). Experiments were therefore performed in the presence of nicardipine, a dihydropyridine blocker, to ascertain that the observed $\mathrm{Ca}^{2+}$ entry could only occur through CRAC channels. Moreover, both tyrosine kinase inhibitors also blocked the sustained $\left[\mathrm{Ca}^{2+}\right]_{\mathrm{c}}$ response to thapsigargin, which is known to be exclusively due to capacitative influx (Takemura et al. 1989). A third inhibitor, lavendustin A, reportedly more specific of EGF receptor tyrosine kinase (Hsu et al. 1991), did not affect Ang II- or thapsigargin-induced $\mathrm{Ca}^{2+}$ influx. Importantly, Ins $(1,4,5)$ $\mathrm{P}_{3}$-mediated $\mathrm{Ca}^{2+}$ release remained unaffected by tyrosine kinase inhibition, a finding which puts tyrosine kinase activation by Ang II downstream of the mobilization of $\mathrm{Ca}^{2+}$ from intracellular stores, as suggested by others on the basis of purely pharmacological studies (Bodart et al. 1995). 

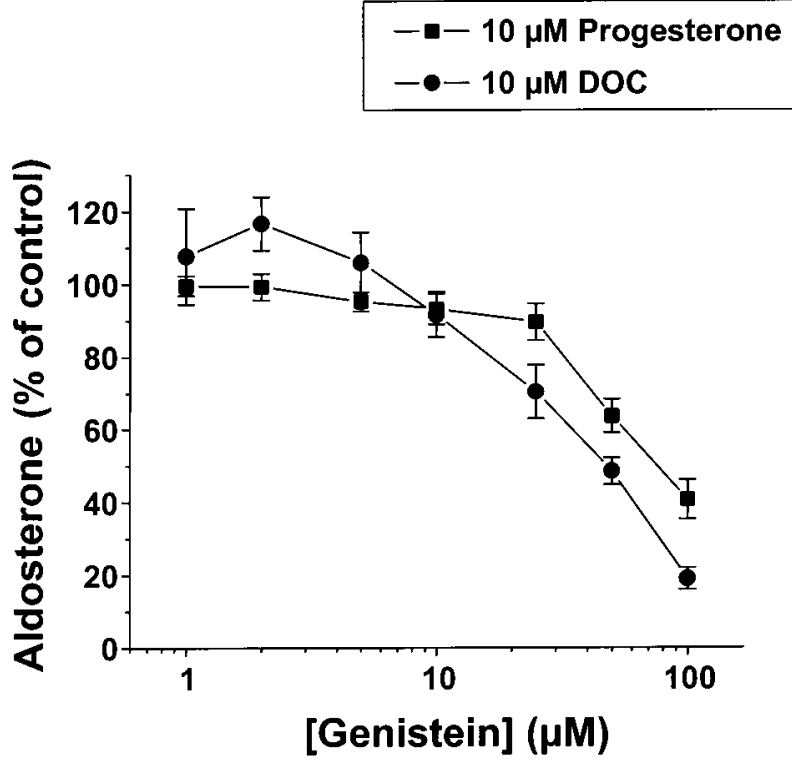

Figure 6 Effect of genistein on the conversion of progesterone and DOC to aldosterone. Freshly isolated bovine glomerulosa cells were incubated for $90 \mathrm{~min}$ at $37^{\circ} \mathrm{C}$ as described under Materials and Methods, in the presence of $10 \mu \mathrm{M}$ progesterone $(\mathbf{a})$ or $10 \mu \mathrm{M}$ DOC $(0)$ and various concentrations of genistein. Aldosterone content in the medium was expressed as percentage of controls in the absence of genistein $\left(16 \cdot 2 \pm 1 \cdot 3 \mathrm{ng} / 10^{6}\right.$ cell/90 min for progesterone and $66 \cdot 3 \pm 6 \cdot 1 \mathrm{ng} / 10^{6} \mathrm{cell} / 90 \mathrm{~min}$ for DOC). Each point is the mean value \pm S.E.M. of between four and six independent experiments.

The biological response to Ang II in various target organs has already been shown to be altered by inhibitors of tyrosine kinase. Thus, for example, in longitudinal strips from guinea pig gastric smooth muscle, tyrosine kinase inhibitors selectively and completely blocked Ang IImediated contraction (Yang et al. 1993). Tyrosine kinase inhibitors also decreased Ang II-stimulated aldosterone production in rat adrenal capsules and cultured bovine glomerulosa cells (Bodart et al. 1995, Kapas et al. 1995). In fact, Ang II can activate tyrosine kinase activity in rat adrenal capsules (Kapas et al. 1995). However, in none of these studies, a functional link with $\mathrm{Ca}^{2+}$ influx was demonstrated.

Since the full aldosterone response to Ang II crucially depends upon capacitative $\mathrm{Ca}^{2+}$ influx (Burnay et al. 1994), agents that alter this influx should also affect mineralocorticoid biosynthesis. Indeed, both genistein and MDHC behaved as powerful anti-steroidogenic compounds, preventing both pregnenolone and aldosterone production. While the potency of these two agents was similar on the first step of the steroidogenic cascade (pregnenolone biosynthesis), genistein appeared to act also on downstream steps since it exerted additional inhibitory effects on Ang II-stimulated aldosterone production. Importantly, lavendustin A, which was without effect on the capacitative influx, did not affect the pregnenolone and aldosterone response to Ang II, thus confirming the causal link between CRAC channel activation by Ang II and the subsequent steroid output.

The hypothesis of additional impact sites for some tyrosine kinase inhibitors along the steroidogenic cascade was further confirmed by three different approaches. First, we performed experiments in which the rate-limiting step of intramitochondrial cholesterol supply to the $\mathrm{P} 450 \mathrm{scc}$ enzyme was bypassed by the addition of 25-OH-Chol. While none of the tested inhibitors affected the early steps of the steroidogenic cascade, genistein clearly inhibited 25-OH-Chol-supported aldosterone production. As expected, lavendustin A was without effect. Secondly, we stimulated steroidogenesis by mimicking a $\mathrm{Ca}^{2+}$ signal in bovine glomerulosa cells through a calcium clamp (Python et al. 1995), thus short-circuiting $\mathrm{Ca}^{2+}$ influx mechanisms. Under these conditions, genistein completely abolished $\mathrm{Ca}^{2+}$-induced aldosterone production. Thirdly, we focused on the late steps of the steroidogenic pathway by measuring progesterone and DOC conversion to aldosterone. Once again, genistein inhibited in a concentrationdependent manner both processes, therefore suggesting that a genistein-sensitive tyrosine kinase also activates one

Table 2 Effect of genistein and genistin on conversion of progesterone and DOC to aldosterone in bovine adrenal glomerulosa cells. Bovine adrenal glomerulosa cells in primary culture were incubated in the presence of either no precursor (basal), progesterone $(10 \mu \mathrm{M})$ or DOC $(10 \mu \mathrm{M})$, with or without genistein $(100 \mu \mathrm{M})$ or genistin $(100 \mu \mathrm{M})$. At the end of a 2-h incubation period, aldosterone was determined in the medium and expressed as percentage of respective controls $(112 \cdot 6 \pm 59 \cdot 0,1024 \cdot 6 \pm 100 \cdot 1$ and $1246 \pm 94 \cdot 2 \mathrm{fmol} / \mathrm{mg}$ protein for basal, progesterone and DOC respectively). Data are the means \pm S.D. of triplicate determinations from two independent experiments

\begin{tabular}{|c|c|c|c|}
\hline & Basal & $\begin{array}{l}\text { + Progesterone } \\
(10 \mu \mathrm{M})\end{array}$ & $\begin{array}{l}\text { + DOC } \\
(10 \mu \mathrm{M})\end{array}$ \\
\hline Control & 100 & 100 & 100 \\
\hline Genistein $(100 \mu \mathrm{M})$ & $2 \cdot 5 \pm 2 \cdot 9^{* *}$ & $37 \cdot 3 \pm 12 \cdot 9^{* *}$ & $58 \cdot 6 \pm 24 \cdot 4^{*}$ \\
\hline Genistin $(100 \mu \mathrm{M})$ & $67 \cdot 1 \pm 8 \cdot 5$ & $102 \cdot 5 \pm 5 \cdot 1$ & $81 \cdot 1 \pm 6 \cdot 4$ \\
\hline
\end{tabular}

${ }^{*} P<0 \cdot 05,{ }^{* *} P<0 \cdot 01$. 
of the very late steps, the conversion of either DOC to corticosterone or of corticosterone to aldosterone. Importantly, genistin, an inactive structural analogue of genistein, was unable to reproduce the inhibitory effects of genistein. The different pharmacology of the two inhibitory effects of genistein on capacitative $\mathrm{Ca}^{2+}$ influx and on the late steps of aldosterone biosynthesis suggests that distinct tyrosine kinases may be involved in these processes.

In summary, we have shown that, in bovine adrenal glomerulosa cells, Ang II promotes capacitative $\mathrm{Ca}^{2+}$ influx and aldosterone biosynthesis through tyrosine kinase activation. The identity and the mechanisms of activation of tyrosine kinase(s) remain to be defined.

\section{Acknowledgements}

The authors are grateful to Liliane Bockhorn, Walda Dimeck and Gisèle Dorenter for their excellent technical assistance. This work was supported by Swiss National Science Foundation Grants \# 31.42178-94 and 31·52779-97 (to A M C) and 32.49297-96 (to M F R).

\section{References}

Barrett PQ, Bollag WB, Isales CM, McCarthy RT \& Rasmussen H 1989 Role of calcium in angiotensin II-mediated aldosterone secretion. Endocrine Reviews 10 496-518.

Berridge MJ 1995 Capacitative calcium entry. Biochemical Journal 312 $1-11$.

Bodart V, Ong H \& De LJan A 1995 A role for protein tyrosine kinase in the steroidogenic pathway of angiotensin II in bovine zona glomerulosa cells. Journal of Steroid Biochemistry and Molecular Biology 54 55-62.

Bradford MM 1976 A rapid and sensitive method for the quantitation of microgram quantities of protein utilizing the principle of protein-dye binding. Analytical Biochemistry 72 248-254.

Burnay MM, Python CP, Vallotton MB, Capponi AM \& Rossier MF 1994 Role of the capacitative calcium influx in the activation of steroidogenesis by angiotensin II in adrenal glomerulosa cells. Endocrinology 135 751-758.

Capponi AM \& Rossier MF 1996 Regulation of aldosterone secretion. Current Opinion in Endocrinology and Diabetes 3 248-257.

Constantinou A \& Huberman E 1995 Genistein as an inducer of tumor cell differentiation: possible mechanisms of action. Proceedings of the Society for Experimental Biology and Medicine 208 109-115.

Ely JA, Ambroz C, Baukal AJ, Christensen SB, Balla T \& Catt KJ 1991 Relationship between agonist- and thapsigargin-sensitive calcium pools in adrenal glomerulosa cells. Thapsigargin-induced $\mathrm{Ca}^{++}$mobilization and entry. Journal of Biological Chemistry 266 18635-18641.

Flemming I, Fisslthaler B \& Busse R 1996 Interdependence of calcium signalling and protein tyrosine phosphorylation in human endothelial cells. Journal of Biological Chemistry 271 11009-11015.

Grynkiewicz G, Poenie M \& Tsien RY 1985 A new generation of $\mathrm{Ca}$ indicators with greatly improved fluorescence properties. Journal of Biological Chemistry 260 3440-3450.

Hajnoczky G, Varnai P, Hollo Z, Christensen SB, Balla T, Enyedi P \& Spat A 1991 Thapsigargin-induced increase in cytoplasmic $\mathrm{Ca}^{++}$ concentration and aldosterone production in rat adrenal glomerulosa cells: interaction with potassium and angiotensin-II. Endocrinology 128 2639-2644.

Hsu CY, Persons PE, Spada AP, Bednar RA, Levitzki A \& Zilberstein A 1991 Kinetic analysis of the inhibition of the epidermal growth factor receptor tyrosine kinase by lavendustin-A and its analogue. Journal of Biological Chemistry 266 21105-21112.
Kapas S, Purbrick A \& Hinson JP 1995 Role of tyrosine kinase and protein kinase $\mathrm{C}$ in the steroidogenic actions of angiotensin II, alpha-melanocyte-stimulating hormone and corticotropin in the rat adrenal cortex. Biochemical Journal 305 433-438.

Lee KM, Toscas K \& Villereal ML 1993 Inhibition of bradykinin- and thapsigargin-induced $\mathrm{Ca}^{2+}$ entry by tyrosine kinase inhibitors. Journal of Biological Chemistry 268 9945-9948.

Marrero MB, Paxton WG, Duff JL, Berk BC \& Bernstein KE 1994 Angiotensin II stimulates tyrosine phosphorylation of phospholipase C $-\gamma$ in vascular smooth muscle cells. Journal of Biological Chemistry 269 10935-10939.

Marshall CJ 1995 Specificity of receptor tyrosine kinase signaling: transient versus sustained extracellular signal-regulated kinase activation. Cell 80 179-185.

Parekh AB \& Penner R 1997 Store depletion and calcium influx. Physiological Reviews 77 901-930.

Pfeiffer F, Schmid A \& Schulz I 1995 Capacitative $\mathrm{Ca}^{2+}$ influx and a $\mathrm{Ca}^{2+}$-dependent nonselective cation pathway are discriminated by genistein in mouse pancreatic acinar cells. Pfluegers Arch: European Journal of Physiology 430 916-922.

Putney JW \& Bird GS 1993 The signal for capacitative calcium entry. Cell 75 199-201.

Python CP, Laban OP, Rossier MF, Vallotton MB \& Capponi AM 1995 The site of action of $\mathrm{Ca}^{2+}$ in the activation of steroidogenesis: studies in $\mathrm{Ca}^{2+}$-clamped bovine adrenal zona-glomerulosa cells. Biochemical Journal 305 569-576.

Rhee SG \& Bae YS 1997 Regulation of phosphoinositide-specific phospholipase C isozymes. Journal of Biological Chemistry 272 15045-15048.

Rohacs T, Bago A, Deak F, Hunyady L \& Spät A 1994 Capacitative calcium influx in adrenal glomerulosa cells: possible role in angiotensin II response. American Journal of Physiology 36 C1246-C1252.

Rossier MF, Python CP, Capponi AM, Schlegel W, Kwan CY \& Vallotton MB 1993 Blocking T-type calcium channels with tetrandrine inhibits steroidogenesis in bovine adrenal glomerulosa cells. Endocrinology 132 1035-1043.

Sargeant P, Farndale RW \& Sage SO 1993 ADP- and thapsigarginevoked $\mathrm{Ca}^{2+}$ entry and protein-tyrosine phosphorylation are inhibited by the tyrosine kinase inhibitors genistein and methyl2,5-dihydroxycinnamate in fura-2-loaded human platelets. Journal of Biological Chemistry 268 18151-18156.

Sharma NT \& Davies MJ 1996 Calcium entry activated by store depletion in coronary endothelium is promoted by tyrosine phosphorylation. American Journal of Physiology 270 H267-H274.

Takemura H, Hughes AR, Thastrup O \& Putney JW 1989 Activation of calcium entry by the tumor promoter thapsigargin in parotid acinar cells. Evidence that an intracellular calcium pool, and not an inositol phosphate, regulates calcium fluxes at the plasma membrane. Journal of Biological Chemistry 264 12266-12271.

Takemura H, Imoto K, Sakano S, Kaneko M \& Ohshika H 1997 Involvement of tyrosine kinase in capacitative $\mathrm{Ca}^{2+}$ entry pathway in rat glioma cells. Research Communications in Molecular Pathology and Pharmacology 98 127-140.

Umezawa K, Hori T, Tajima H, Imoto M, Isshiki K \& Takeuchi T 1990 Inhibition of epidermal growth factor-induced DNA synthesis by tyrosine kinase inhibitors. FEBS Letters 260 198-200.

Yang SG, Saifeddine M, Laniyonu A \& Hollenberg MD 1993 Distinct signal transduction pathways for angiotensin II guinea pig gastric smooth muscle: differential blockade by indomethacin and tyrosine kinase inhibitors. Journal of Pharmacology and Experimental Therapeutics 264 958-966.

Received 22 December 1998

Revised manuscript received 12 May 1999

Accepted 20 May 1999 